\title{
MITHRAS, SOL INVICTUS, AND THE ASTRAL PHILOSOPHICAL CONNECTIONS
}

\begin{abstract}
Summary: The main concepts used in this article are the dichotomy and differences between the two main groups of theories regarding the origins of the Roman mystery cult of Mithras: namely the school of the great Belgian scholar Franz Cumont, who considered Mithraism in the Roman world as an essentially Iranian cult adapted to the new cultural Hellenistic-Roman context and the theory of the 19th century German scholar K. B. Stark, respectively (revived in the seventies of the 20th century by academics like R. Beck, J. R. Hinnells, St. Insler, R. Gordon, and A. Bausani), who considered that the Roman cult of the solar god Mithras was a new mystery cult, which was born in the Roman world because of the Hellenistic scientific discovery of the precession of the equinoxes. My conclusion is that the Roman cult of Mithras, fused with the cult of Sol Invictus (the Hellenistic-Roman cult of the Unvanquished Sun), has more things Iranian than the name of the central deity of this initiation-mystery cult (despite its undeniable HellenisticRoman and astrological-astronomical elements).
\end{abstract}

Key words: Mithras, Sol Invictus, Iran, Greek-Hellenistic Astronomy, Greek-Roman Planetary gods, Mysteries, Rome

This small study is an analysis of certain essential (and controversial) points of the history of Mithraism that can shed some light on the doctrine or religious ideas of this mystery cult, which has left its mark on the Roman Empire, especially during the 2nd and 3rd centuries after Christ.

The name of Mithras in Latin and Ancient Greek is of Indo-Iranian origin. It is the name of the sun god or rather of a solar god; in the $R g$-Veda we encounter the god Mitra (meaning Friend in the Vedic language), who is another name for the god Surya (the Sun). This god is mentioned in one of the hymns of this oldest of the four Vedas. The ancient Iran has also a god called MiPra-(Mithra) in the Avesta, an ancient god who was not relegated by the prophet ZaraPuštra (Zarathustra/Zoroaster of the ancient Greeks) to the rank of the daeva- (ancient gods, which became demons in Mazdeism/Zoroastrianism), but he is on the side of the Supreme Creator God AhuraMazda and therefore on the side of Good, Truth, and Righteousness, as opposed to the Principle of Evil, Lie, and Injustice (Angra Mainyu). The Avestan god MiPra- 
(ancient Persian $\mathrm{Miça-)}$ is also a solar god and a protector of oaths, compacts, pastures, and herds of cattle, like his Vedic counterpart. ${ }^{1}$

It appears that, apart from the name, there is little connection between the Roman god Mithras and his Iranian counterpart Mithra. It is true, nevertheless, that in both Parthian Arsacid Iran and in Armenia the god Mihr or Meh(e)r was worshipped by Kings, nobles, and commoners (Mihr is the Parthian or Arsacid Pahlavi form of the ancient Iranian word Mithra; we do not analyze here the disputed question of the religion professed by the ancient Persians and especially by their "Kings of kings" during the age of the Achaemenid dynasty; it seems, however, that Darius III Codomanus, according to Q. Curtius Rufus, believed both in Ahura Mazdā and in Mithra, under the Latin names of Iuppiter and Sol, respectively; Plutarch in his Vita Alexandri mentions clearly Mithras/Míp $\alpha \varsigma$ as an Iranian god worshipped by the Persians from the times of the Persian "King of kings" Darius III Codomanus and Alexander the Great, King of Macedon and Asia, if not even before). ${ }^{2}$ The king of Pontus, Mithridates (or Mithradates) VI Eupator, the implacable enemy of the Romans, like many of his princely and royal ancestors, bore a name that signified "the gift of Mithra"; nomen est omen, as the ancient Romans said, and even more so for a royal and dynastic name. In Commagene (South-eastern Anatolia, at the frontier of Syria) the impressive sculptures and royal reliefs of Nemrud Dagh include a representation of syncretic Greek and Iranian gods (Zeus-Oromasdes, Heracles-Artagnes/VerePragna, Mithra-Apollon-Helios) as divine protectors of the Hellenistic-Iranian royal dynasty of the kingdom of Commagene. ${ }^{3}$ The first classical testimonies of the existence of a cult of Mithras in the Roman Empire or in the Anatolian regions subject to indirect Roman rule were Statius' poem Thebais (I 716 ff.) and Plutarch's Vita Pompeii (XXIV 7). ${ }^{4}$ Statius mentions the Persian cave of Mithra and the sacrifice of the bull

\footnotetext{
${ }^{1}$ Eliade, M.: Istoria Credinţelor şi Ideilor Religioase [Romanian translation by C. Baltag from Histoire des Croyances et Idées Religieuses. Paris 1978]. Vol. II. Bucureşti 1991, 280-282, 294-301; Eliade, M. - Culianu, I. P. - Wiesner, H. S.: Dicţionar al Religiilor [Eliade, M. - Culianu, I. P.: Dictionnaire des Religions. Paris 1990]. Bucureşti 1993, 235-236, 269-277, esp. 276, for Mithra as one of the three gods (along with Sraoša and Rašnu) that judged the souls of the deceased, before they pass the Cinvant bridge]; WALD, L. - SLUŞANSCHI, D. - BĂLTĂCEANU, F.: Introducere în Studiul Limbii şi Culturii Indo-Europene. Bucureşti 1987, 162-163.

${ }^{2}$ Curt. Ruf. De reb. gest. 3. 3; 4. 10; Plut. Vita Alex. XXX 4; UlANSEY, D.: I Misteri di Mithra. Cosmologia e salvazione nel mondo antico [The Origins of the Mithraic Mysteries-Cosmology and Salvation in the Ancient World. Oxford University Press, 1989]. Trad. di M. T. Rezza e L. Tucci. Roma 2001, 16-19 for the Cumont thesis of the Iranian origins of Mithraic mysteries.

${ }^{3}$ ELIADE: Istoria (n. 1) II 294. The name of Mithridates or (rather and more correct) Mithradates, meaning something like "given by Mithra/the gift of Mithra", a name given to many kings of Pontus (Hellenized Iranians from North-eastern Asia Minor) points to a worship of Mithra in those Anatolian moun-

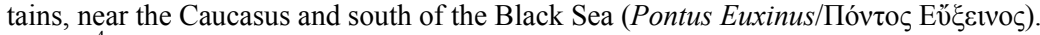

${ }^{4}$ SANZI, E. - SFAMENI, C.: Magia e Culti Orientali per la Storia Religiosa della Tarda Anttichità. Cosenza 2009, 98-99; SANZI, E.: IVPPITER OPTIMVS MAXIMVS DOLICHENVS. Un "culto orientale" fra tradizione e innovazione: riflessioni storico-religiose. Roma 2013, 28-29, nn. 37-38; STROOTMAN, R.: The Heroic Company of My Forebears: The Ancestor Gallerie of Antiochos I of Kommagene at Nemrut Daği and the Role of Royal Women in the Transmission of Hellenistic Kingship. In CoşKUN, A. MCAuley, A. (eds): Seleukid Royal Women. Creation, Representation and Distortion of Hellenistic Kingship in the Seleukid Empire [Alte Geschichte Historia-Einzelschriften 240]. Stuttgart 2016, 225.
} 
(those above mentioned verses begin interestingly with an invocation addressed to the god Phoebus Apollo), while Plutarch in his Vita Pompeii mentions the pirates of Cilicia that they performed the strange rituals of the god Mithras on the mountain Olympus of Lycia and these weird Mithraic rites have endured until Plutarch's day, according to the very words of the author of Chaeronea. We can infer from these statements that around the 1st century BCE - 1st century CE the cult of Mithras, probably structured as it will be known in the Roman Empire during the 2nd and 3rd centuries CE, was already in existence. This cult of Mithras will endure in the Roman Empire well into the 4th century CE, although the distinction between Mithras and Sol (the ancient Roman sun god, who was gradually identified or overlapped with the Greek sun god Helios, with Phoebus Apollo as the divine force of the solar light,

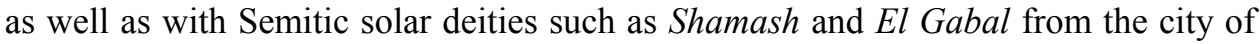
Emesa in Syria) was more and more blurred or even it became non-existent as time went by.

Modern theories about the character of the Mithras cult could be well grouped into two main categories: the first one, originating from the Belgian scholar Franz $\mathrm{Cu}-$ mont, considers that the Roman cult of Mithras is essentially an Iranian cult, which has been brought to the Hellenistic and later Roman World via the so called "Mages Hellenisés" from Anatolia (a vast land where Hittite, Lydian, Phrygian, Carian, and Lycian Anatolian cultures interacted with the ancient Greek and ancient Iranian cultures, a contact which was especially intense during the Achaemenid and Hellenistic times) and, although it has assumed in time a Hellenistic-Roman character (a Greek and later a Latin form of an Iranian god), it is essentially an Iranian born cult. ${ }^{5}$ This thesis presupposes the existence of an intermediary group, the so called Hellenized Iranian Magi that were the transmission link between ancient Persia and Parthia and the Roman Empire and were therefore located in Armenia and Asia Minor, lands where the Iranian and the Greek cultural spheres interfered for centuries during the Achaemenid and especially during the post-Achaemenid (Hellenistic) times. The existence of such a priestly group of Iranian religion and Greek culture, despite its great plausibility, has never been demonstrated with historical, epigraphic, or archaeological sound proofs. The great erudition and scholarly logic of Cumont has nevertheless given birth to the Cumontian School in the interpretation of Roman Mithraism, a school which has dominated the scholarly approaches on this old gone religion for almost three quarters of the past century.

Another line of interpretation of the Mithraic religious phenomenon has been born very early, in the 19th century, within the work of the German scholar K. B. Stark. According to Stark's view, the figures or iconographical characters that made up the central scene of the Mithraic tauroctony were planets or even stars and constellations (astral bodies in any case). This fact suggested further that it was represented in this myth as a map of the night sky and therefore the cult of Mithras has had an astronomical-astrological substance. ${ }^{6}$ This thesis, largely forgotten during the first

\footnotetext{
${ }^{5}$ ULANSEY: I misteri (n. 2) 16-18.

${ }^{6}$ ULANSEY: I misteri (n. 2) 24 ff.
} 
three quarters of the 20th century, has been reconsidered beginning with the seventies. In 1971, during the First International Congress of Mithraic Studies (Manchester), John R. Hinnells and Richard Gordon had advanced the hypothesis that Roman Mithraism was a totally new cult (in relationship with the old Iranian cult of the god Mithra), using as central divine character a god bearing an Iranian name and detail elements of Hellenistic-Iranian imprint to give them an esoteric and exotic flavor, in order to attract new adepts. ${ }^{7}$ J. R. Hinnells sustains nevertheless that a central Iranian nucleus (presumably of religious ideas) was still present in the Roman cult of Mithras. ${ }^{8}$

The subsequent scholarship has been divided between these points: an Iranian Hellenized religious cult adapted to the new conditions of the Roman Empire and to the Roman forma mentis or an entirely new mystery cult, born either in the Near East or even in Italy and Rome and that spread to the provinces, especially the provinces of the European limes of the Roman Empire, from Britannia and the two Germaniae (Inferior and Superior) to the Pannoniae, Daciae, and the two Moesiae (Superior and Inferior, respectively). ${ }^{9}$ In 1973, the Canadian Classicist scholar Roger Beck advanced the idea that the Mithraic tauroctony and the animal figures that appear alongside Mithra (the sacrificed Bull, the Dog, the Snake, the Raven, and the Scorpion), as well as the ear of wheat sprouting from the Bull's tail in the moment of sacrifice, were in fact the constellations of Taurus, Canis Minor, Hydra, Corvus, Scorpius or Scorpio, and Spica, respectively, and he gradually developed this hypothesis into a theory; this theory was defended in the Second International Congress of Mithraic Studies (in 1975 at Teheran) by the Iranologist Stanley Insler. He (Insler), however, unlike Beck, argue that these constellations represented in the Mithraic tauroctony were those visible in the heliacal setting of the Taurus constellation, therefore in a precise astronomical moment of the solar year (while Beck simply referred to constellations visible to the naked human eye during the whole astronomical year). Insler instead refers to the constellations of Taurus, Scorpio, Hydra, Corvus, Krater/Kylix, Leo Maior, and Canis Minor and has put into relationship these star clusters with the animals, plants, and objects which appear on the Mithraic relief scenes of the tauroctony (the Bull, the Scorpion, the Snake, the Raven, the Cup, the Lion, and the Dog). ${ }^{10}$

The ideas of Stark, Beck, and Insler proved to be seminal. Beck, in fact, has noticed that along the ecliptic, between the stars Aldebaran and Antares (in the constellation of Taurus and Scorpio, respectively), there appear all the constellations corresponding (in name and approximate form) to the animals represented in the Mithraic tauroctony. In 1978 at Rome, during an International Seminar on Mithraism, the great Italian scholar Alessandro Bausani has advanced another idea, based also on the Beck-Insler theory, but also on the ideas of the science historian Willy Hartner that the Mithras'sacrifice of the Bull represented in fact an age old Near Eastern and Middle Eastern mythological and iconographical topos of the battle between Bull and

\footnotetext{
${ }^{7}$ SANZI-SFAMENI (n. 4) 200-201.

${ }^{8}$ ULANSEY: I misteri (n. 2) 21.

${ }^{9}$ ULANSEY: I misteri (n. 2) 13-16; SANZI-SFAMENI (n. 4) 15-17, 99-102, 199-209.

${ }^{10}$ ULANSEY: I misteri (n. 2) 28-29; SANZI-SFAMENI (n. 4) 202-203.
} 
Lion, a myth going back to ancient Sumer (the confrontation and deadly combat between the hero Ghilgamesh, the Lion, and the bull-like monster Khumbaba, an epic fight that saw the death of Enkidu, Ghilgamesh's brother in arms). ${ }^{11}$ Moreover, this mythical battle would have reflected the apex of the Lion's constellation astronomical procession in the sky, when the Lion (Leo) "kills" the Bull (Taurus) that descends below the horizon (which fact is also a precise moment of the astronomical year). As David Ulansey rightly remarks, although Bausani's theory refers to a precise moment in time (during the astronomical year), not all the constellations visible at that particular moment were present in the plastic representations of the Mithraic tauroctony, inside the mithrea. ${ }^{12}$ The historian of ancient Rome Michael Speidel considers that the Mithraic bull-slaying episode represents the equatorial summer constellations from Taurus to Scorpio, but Mithras himself is represented (according to Speidel's own theory) by the constellation of Orion. ${ }^{13}$

The thesis of David Ulansey about the astronomical character of the Mithraic mysteries is much elaborated and we must here focus only on the essential ideas, which are the following:

1. The origin of the Mithra cult in the Roman Empire cannot be reduced to the transfer of an Iranian god to the Hellenistic and then to the Roman world. Even in the most Cumontian of perspectives, a changed cultural, ethnic, and religious setting means a different cult form at least, if not a different religion altogether.

2. There are iconographical, narrative (philosophical), and scientific testimonies (breakthroughs in ancient Greek astronomy and mathematics during the Hellenistic age, namely the discovery of the astronomical phenomenon of the precession of Spring and Autumn Equinoxes by the 3rd and 2nd centuries astronomers Aratos of Soloi and Hipparchus) and the philosophical theories of the Stoics from Tarsus like Athenodorus in the times of Augustus (likewise the ideas of other philosophers, from Plato's Timaeus dialogue to the writings of Poseidonius of Apamea and Philodemus of Gadara) that all give credence to the idea of the apparition of a new cult which in fact has as central mystery the precession of the equinoxes.

3. The precession of the equinoxes (from Bull/Taurus and Scorpion/Scorpius to Ram/Aries and Balance/Libra, about two millennia before the birth of Christ and the apparition of the cult of Mithras in the Roman Empire) was the central part of the Mithraic cult; moreover, on iconographical grounds taken from the Mithraic reliefs of tauroctony and from Greek-Roman art, Ulansey has concluded that the hero Perseus, worshipped at Tarsus as a local god, was identified with Mithras, seen by these intellectual founders as the deity able to move the Heaven's canopy and cause the precession of equinoxes. All these religious concepts have appeared in a world where the heliocentric theory ideated by Aristarchus of Samos was not a diffused idea and the geocentric conception of the Universe, with all its astronomical paraphernalia,

\footnotetext{
${ }^{11}$ The problem that remains here is the following: in the Epic of Ghilgamesh the Bull metaphor is applied sometimes even to Ghilgamesh and to Enkidu also.

${ }^{12}$ ULANSEY: I misteri (n. 2) 30-31.

${ }^{13}$ UlANSEY: I misteri (n. 2) 31-33; SANZI-SFAMENI (n. 4) 202-203.
} 
was still prevalent (the astronomer and geographer Ptolemy from the 2 nd century CE being the most known figure of this geocentric astronomical school); in that perspective, Ulansey thinks that a group of intellectuals (astronomers and Stoic philosophers) from Tarsus has in fact ideated a new god, named Mithras, who was responsible for the displacement of the whole sky of the so called "fixed stars", in order to explain the phenomenon of equinoctial precession, in the mental boundaries created by a geocentric conception of the Cosmos. ${ }^{14}$

The problem of considering the Mithras mysteries in the Roman Empire as being entirely a cult reflecting the scientific discovery of the precession of the equinoxes is that the central character, Mithras, is not only a cosmic god, but primarily a salvation deity. Another substantial objection to the exclusive astronomical character of Mithras is his lack of exact identification with a precise constellation: while both Michael Speidel and David Ulansey identify the figures represented in the Mithras'scene of slaying the Bull with the visible constellations located on (above) and/or below the celestial equator (the celestial position of the Taurus constellation during the Spring Equinox and of the Scorpio constellation during the Fall Equinox some two thousand years before Roman Mithraism ever took shape; during the Greek-Roman Age, in the 1st millennium BCE, the Age of the Bull was long before replaced by the Age of the Ram, the Spring and Fall equinoxes taking place under the constellations of the Aries/Ram and of the Libra/Balance, respectively), Mithras himself has been identified by Michael Speidel with the constellation of Orion, while David Ulansey prefers rather the constellation of Perseus; while Cautes and Cautopates, the two Dadophoroi, were seen by them as personifications of the Spring and Fall Equinoxes, respectively. $^{15}$

${ }^{14}$ UlANSEY: I misteri (n. 2) 16-23, 24-33, esp. 30-32, 34-39 ff. passim.

${ }^{15}$ Ulansey, D.: The Origins of the Mithraic Mysteries: Cosmology and Salvation in the Ancient World. Oxford 1991, 93 apud SANZI-SFAMENI (n. 4) 204, n. 12; UlANSEY: I misteri (n. 2) 58-62 (the moment when the constellation of the Lion/Leo was above the constellation of the Bull/Taurus, as the climax of the battle between Lion and Bull; during the beginnings of the Christian Era, in the 1st century $\mathrm{CE}$, the Spring and Fall equinoxes began to fall at the end of the zodiac signs of the Pisces and of the Virgo respectively); for the moment when the constellation of Perseus rose above the Bull vide ULANSEY: I misteri (n. 2) 59-63, esp. 60-61 and 62-63. The problem that arises with this interpretation is why the name chosen for this supposedly hyper-cosmic deity responsible with the precession of the equinoxes was Mithras, and neither Perseus nor Orion, the names of the constellations involved in this astronomical phenomenon?! The Heaven was the abode of the sky gods and of some deified heroes of Greek-Roman mythology, such as Heracles, Perseus, and Orion, but none of them became the central god of the new mystery cult, but only the obscure new god with a clearly old Indo-Iranian name, Mithras. This fact in itself deserves some explanation: if Mithraism in the Roman Empire would have been only a new born Hellenistic-Roman mystery cult of astronomical-astrological origins, why the name of the central deity of this cult was that of an age old Indo-Iranian solar god? It must have been a bit more of Iran in the Roman god Mithras than merely a divine name: that was so because, for a simple new mystery cult with essentially Greek-Roman roots in mythology and astronomy-astrology, the Greek heroic names (Orion or Perseus) of constellations involved in the phenomenon of the precession of equinoxes would have been much more appropriate, and not the name of a foreign Parthian-Persian (Iranian) solar deity, like Mithras truly was for most Romans in the 1st century BCE, when Plutarch first writes about this cult of Persian mysteries among the pirates of Cilicia. 
The astronomical character of the Roman cult of Mithras is further reinforced by the seven degrees of Mithraic initiation: Corax, Nymphus/Cryphius, Miles, Leo, Perses, Heliodromus, and Pater. These seven degrees were under the protection of seven Roman gods and seven planets (in fact six visible Planets and our star the Sun), respectively: Mercurius, Venus, Mars, Iuppiter, Luna, Sol, Saturnus (in Greek terms Hermes, Aphrodite, Ares, Zeus, Selene, Helios, and Kronos/Chronos), corresponding to the planets/(or star in the case of the Sun) Mercury, Venus, Mars, Jupiter, Moon, Sun, and Saturn. Every degree had a special initiation ritual. ${ }^{16}$ The Christian saint martyr Justin the Philosopher (Iustinus Philosophus) sees in his Prima Apologia the Mysteries of Mithras (namely the offering of a loaf of bread and a cup of water, instead of holy wine) as a demonic parody of the Christian Sacrament of the Holy Communion (the Rite of the Eucharist). At the same time, the testimony of the philosopher Celsus and of the Neoplatonist philosophers (for example Porphyrius in his De antro nympharum) underlined the partnership between Sol and Mithras as they ascend together in the chariot to (or beyond) the Heavens. In the same vein, the treatise Contra Celsum gives the image of the so called "doctrine of the Persians" (doctrina Persarum) and of the initiation in the Mysteries of Mithras, by the symbolic configuration of the planets' sphere and of the "sphere of fixed stars", as well as the celestial stairway with seven gates and the final eighth gate. There is a correspondence between the gates and the gods, as well as the metals: the first gate is made of lead, the second of tin, the third of bronze, the fourth of iron, the fifth out of a metal alloy, the sixth of silver, and the seventh of bronze. The first it is attributed to Kronos (Saturn), because the lead symbolizes the slowness of this planet (we would have expected here Hermes-Mercurius, the patron and divine protector of the Corax Mithraic degree); the second to Aphrodite (Venus), because of the brilliance of tin (this truly corresponds to Nymphius/Cryphius); the third to Zeus-Iuppiter, because of the solidity of the base of the bronze gate (here anyone would have expected Ares-Mars, the divine patron and protector of the Mithraic Miles); the fourth to Hermes, because of the resistance of iron; the fifth to Ares, because many metals are included in the alloy, which is a variegated and composite substance. The sixth gate, of silver, corresponds to Selene; and the seventh gate of gold, to the Sun (Helios). This is the way to Heaven of the initiate's soul and we can see that this succession of heavenly metal gates does not reproduce the succession of planets presiding over the seven degrees of Mithraic initiation: in fact the stairway begins with lead, associated with Saturn, while the last (supreme) degree of Mithras'mysteries is Pater, under the sign of Saturn (Kronos/Chronos); the second gate, associated to Venus (Aphrodite, both the goddess and the planet), is made out of tin (normally, copper would have been the normal metal for Venus-Aphrodite, Kypris and Kypros being the surname of the goddess of love and the name of the island of Cyprus, respectively, the birthplace of Aphrodite, as well as one of the Greek names for copper); the third gate made out of bronze (Gr. chalkos), one would expect that this will correspond to Miles and be under

${ }^{16}$ SANZI (n. 4) 32-33: this is confirmed by Hieronymus' epistle Ad Laetam and the inscriptions painted on the Mithraeum of Santa Prisca in Rome. 
the protective shield of Mars (Ares), but instead is under the aegis of Jupiter-Zeus; the fourth gate is under the sign of Hermes, whose metallic element is iron (one would expect here Jupiter-Zeus as patron of the Leo initiate of Mithras and bronze as metallic alloy of the gate, iron being usually associated with Mars-Ares and not with Mercury-Hermes); the fifth gate, created from a metal alloy, is associated with AresMars, and not with the Moon/Luna-Selene, as Mithras' fifth initiation degree of Perses presupposes); the sixth gate, of silver, corresponds with Selene-Luna (the Moon), and not with Helios-Sol (the Sun), as the Mithraic degree of Heliodromus presupposes; finally, the seventh gate is made out of gold and corresponds to the Sun (Helios-Sol), when anyone could have suspected here to be the gate corresponding to Pater, under the sign of Saturn (Kronos/Chronos). The eighth gate could have eventually represented the way to liberation from this world, a way out of this Universe or Kosmos. ${ }^{17}$

To conclude our overview of the cult of Mithras, the inscription of Carnuntum shows not only the adoption of Mithras by the former and reigning Tetrarch emperors as a personal divine protector, but also as a deity protecting both the imperial power of the reigning emperors and the Imperium Romanum or the Roman Empire as a whole. $\mathrm{He}$ is a strange god with an Iranian name that was correlated with and vanquished the Sun god ( $\mathrm{Sol}$ ) and then has forged a divine partnership with Sol (Helios-Apollon) and eventually ascends to Heavens in the chariot of the Sun; ${ }^{18}$ moreover, Mithras became the Sol Invictus, the Invincible Sun, according to the same inscription of Carnuntum. He presides over the salvation of his worshippers, who underwent hard initiation rituals in order to advance through the ranks and achieve individual salvation of the soul (a very soldier like mentality, proper to most Roman military men and also to many Roman civil servicemen and befitting a warrior god of Eastern origin); he is correlated with astronomy (very technical concepts like celestial equator, ecliptic or the apparent movement of the Sun, the dating of the equinoxes, etc.), with Cosmic Time (we do not dwell here on the possible correlation between Mithras and the Leontocephalos god of Time), with astral bodies and possible also to the way out of this Cosmos. His demise appears as strange as his ascension and age of glory; a new Eastern religion which owes many doctrinal elements and concepts to Mithraism and Neoplatonism, Christianity, has vanquished or rather has absorbed the Mysteries of Mithras (although officially abhorred them). My modest conclusion could be paradoxical: Mithras Sol Invictus is a complete metamorphosis of the Old Indo-Iranian Sun god into a salvation deity connected with astral bodies, with the afterlife destiny of the human souls, and also with the life founding sacrifice of the cosmic bull, contrary to the ideas expressed in the Iranian Bundahishn. This sole element (namely the sacrifice of the Primordial cosmic Bull by Mithras' dagger, instead of the intervention

${ }^{17}$ SANZI (n. 4) 34-36, and esp. 35-37: Mithras is seen in the inscription from Carnuntum AD 307 by the religiosissimi Iovii et Herculii Diocletianus, Maximianus, Galerius, and Licinius, as the fautor imperii sui and the worship of Mithras by the Emperor Julian the Apostate/Iulianus Apostata, vide SANZI (n. 4) 36-37 and 57, n. 61: CIMRM II 1698 "D(eo) S(oli) I(nvicto) M(ithrae) fautori imperii sui/Iovii et Herculii/religiosissimi/Augusti et Caesares/sacrarium/restituerunt."

${ }^{18}$ ULANSEY: I misteri (n. 2) 112-120. 
of the Evil Principle Angra Mainyu, the enemy of Good, Truth, and Righteousness i.e. of Ahura Mazdā/the Creator God) is essential, in my humble opinion, to make the Roman Mithras a new astral god born out of the rock (Mithras petrogenitus, Mithras born out of stone), and not a simple continuation of his supposed Persian forefather. ${ }^{19}$

Dan-Tudor Ionescu

The Metropolitan Library of Bucharest

Romania

${ }^{19}$ ALBRILE, E.: Inventare Zoroastro. Riflessi della religione iranica nel mondo greco. Quaderni di studi indo-mediterranei 8 (2015) 151-170, esp. 158 for astronomical connections in Zoroastrianism and in Greek thought, 167-168 for the soteriological role of the sacrificial Bull and the future Saviour of Humanity, Saošyant, passim. For the discussion on the theories concerning Mithraism and ancient Astronomy-Astrology vide GNOLI, T.: Mithras and the Stars: A Note. In MAETSCH, M. - WeBER, D. - DURKINMEISTERERNST, D. (eds): Ancient and Middle Iranian Studies Proceedings of the 6th European Conference of Iranian Studies, Vienna, 18-22 of September 2007 [Iranica 19]. Wiesbaden 2010, 77-86. 
